\title{
DISTRIBUSI PENDAPATAN ANTAR DAERAH DI PROVINSI SULAWESI UTARA
}

\author{
Bella Fitria Laloan \\ Gene H. M. Kapantow \\ Oktavianus Porajouw
}

\begin{abstract}
This study aims to determine the distribution of income among regions in North Sulawesi Province. This research was conducted for 4 months from October 2017 until February 2018 in North Sulawesi Province. In this study the data used were secondary data obtained from the Central Bureau of Statistics (BPS) of North Sulawesi Province. The data was processed using Gini Index analysis method (calculated BPS data) and Williamson Index and presented in tabular form. The results of the research showed that the level of the uniformity of the income distribution among regions in North Sulawesi tended increase as incated by the value of Williamson Index which raised from 0,475 in 2012 to 0,543 in 2016. While the income distribution in North Sulawesi was relative even indicated by the value of Gini Index in 2012 0.43 dropped 0,39 in 2016." "ghmk*.
\end{abstract}

Keywords: income distribution, index value, North Sulawesi Province.

\begin{abstract}
ABSTRAK
Penelitian ini bertujuan untuk mengetahui distribusi pendapatan antar daerah di Provinsi Sulawesi Utara. Penelitian ini dilakukan selama 4 bulan yaitu dari bulan Oktober 2017 sampai bulan Februari 2018 di Provinsi Sulawesi Utara. Pada penelitian ini data yang digunakan adalah data sekunder yang diperoleh dari Badan Pusat Statistik (BPS) Provinsi Sulawesi Utara. Data tersebut diolah menggunakan metode penelitian analisis Indeks Gini (data BPS dihitung) dan Indeks Williamson dan disajikan dalam bentuk tabel. Hasil penelitian menunjukkan bahwa distribusi pendapatan antar Kabupaten/Kota di Sulawesi Utara tingkat ketidakmerataanya meningkat ditunjukan dengan nilai Indeks Williamson sebesar 0,475 ditahun 2012 menjadi 0,543 di tahun 2016. Sedangkan distribusi pendapatan di Sulawesi Utara dengan melihat Indeks Gini Sulawesi Utara relatif merata ditunjukan dengan nilai Indeks Gini pada tahun 2012 0,43 turun menjadi lebih merata di tahun 2016 dengan nilai Indeks Gini 0,39. *ghmk*.
\end{abstract}

Kata kunci: distribusi pendapatan, nilai indeks, Provinsi Sulawesi Utara.

\section{PENDAHULUAN}

\section{Latar Belakang}

Pertumbuhan ekonomi merefleksikan perkembangan aktifitas perekonomian daerah yang ditandai dengan pergerakkan roda ekonomi daerah melalui aktivitas produksi, konsumsi dan investasi yang berdampak pada penyerapan tenaga kerja dan peningkatan kesejahteraan masyarakat. Pertumbuhan ekonomi akan lebih bermakna apabila dapat dinikmati oleh seluruh lapisan masyarakat secara merata yang sering kali diikuti dengan perubahan struktur pendapatan, terutama bagi Negara yang sedang berkembang (Tambunan, 2001). Secara filosofis suatu proses pembangunan dapat diartikan sebagai "upaya yang sistematik dan ber-kesinambungan 
untuk menciptakan keadaan yang dapat menyediakan berbagai alternatif yang sah bagi pencapaian aspirasi setiap warga yang paling humanistik" dengan perkataan lain proses pembangunan merupakan proses memanusiakan manusia (Rustiadi, 2011).

Pelaksanaan pembangunan bersentuhan langsung dengan sumber daya yang sangat berpengaruh terhadap hajat hidup orang banyak yaitu tanah. Tanah merupakan sumber daya alam yang sangat penting untuk kehidupan umat manusia, semua kegiatan manusia dan pembangunan memerlukan tanah.

Distribusi pendapatan merupakan faktor penting dalam menentukan keadaan kesejahteraan masyarakat pada umumnya. Distribusi pendapatan merupakan masalah perbedaan pendapatan antara individu yang paling kaya dengan individu yang paling miskin. Semakin besar jurang pendapatan maka semakin besar pula variasi dalam distribusi pendapatan. Maka disini peran pemerintah diperlukan dalam menyelaraskan pertumbuhan ekonomi dengan distribusi pendapatan, sehingga ketika pertumbuhan ekonomi meningkat, maka kesejahteraan masyarakat akan distribusi pendapatannya pun juga dapat dirasakan secara merata oleh masyarakat.

Masalah besar yang dihadapi negaranegara sedang berkembang seperti Indonesia adalah disparitas (ketimpangan) distribusi pendapatan dan tingkat kemiskinan. Ketimpangan pembangunan selama ini berlangsung dengan berwujud dalam berbagai bentuk, aspek, dan dimensi. Seperti ketimpangan hasil pembangunan misalnya dalam hal pendapatan perkapita atau pendapatan daerah, dan ketimpangan kegiatan atau proses pembangunan itu sendiri. Munculnya kawasan-kawasan kumuh di tengah beberapa kota besar, serta sebaliknya hadirnya kawasan-kawasan pemukiman mewah di tepian kota atau bahkan di pedesaan adalah suatu bukti nyata dari adanya suatu ketimpangan yang terjadi dan perbedaan gaya hidup masyarakat merupakan bukti lain dari ketimpangan.

Angka kemiskinan di Sulawesi Utara melalui Data BPS terakhir pada bulan Maret
2017 sebesar 8,10\% atau sebanyak 198,88 ribu jiwa dan berada dibawah angka nasional. Penduduk miskin di Sulawesi Utara masih di dominasi penduduk di daerah pedesaan, dari 198,88 ribu jiwa penduduk miskin pada data akhir bulan Maret 2017, hampir $70 \%$ nya berada di daerah pedesaan. Di pedesaan $10,77 \%$ (139,05 ribuh jiwa) sedangkan di perkotaan sebesar 5,14\% (59,82 ribuh jiwa). Pada Maret 2017 juga terdapat presentase kemiskinan sebesar 5,63\% antara pedesaan dan perkotaan, semakin menegaskan bahwa kantong kemiskinan berada di pedesaan. Pada periode September 2016 ke Maret 2017 terjadi kenaikan garis kemiskinan sebesar Rp 14.526, yaitu dari $\mathrm{Rp} 318.984$, per kapita per bulan pada September 2016 menjadi Rp 333.510, per kapita per bulan pada Maret 2017. Artinya jika ada rumah tangga yang mempunyai 2 anggota rumah tangga, akan dikatakan miskin jika pengeluaran rumah tangga tersebut kurang dari Rp 667.020. Sistem distribusi pendapatan menentukan bagaimana pendapatan wilayah yang tinggi mampu menciptakan perubahanperubahan dan perbaikan-perbaikan dalam kehidupan bernegara, seperti mengurangi kemiskinan, pengangguran dan kesulitankesulitan lain dalam masyarakat. Distribusi pendapatan yang tidak merata tidak akan menciptakan kemakmuran bagi masyarakat secara umum. Sistem distribusi yang tidak proporsional hanya akan menciptakan kemakmuran bagi masyarakat tertentu saja, sehingga ini menjadi isu yang sangat penting dalam menyikapi tingginya angka kemiskinan hingga saat ini. Untuk itulah peneliti tertarik menganalisis distribusi pendapatan antar daerah di Provinsi Sulawesi Utara.

\section{Distribusi Pendapatan}

Distribusi pendapatan merupakan masalah perbedaan pendapatan antara individu yang paling kaya dengan individu yang paling miskin. Semakin besar jurang pendapatan maka semakin besar pula variasi dalam distribusi pendapatan. Maka disini peran pemerintah diperlukan dalam menyelaraskan pertumbuhan ekonomi dengan distribusi pendapatan, sehingga ketika pertumbuhan ekonomi meningkat, maka 
kesejahteraan masyarakat akan distribusi pendapatannya pun juga dapat dirasakan secara merata oleh masyarakat. Ketimpangan pembangunan selama ini berlangsung dengan berwujud dalam berbagai bentuk, aspek, dan dimensi. Seperti ketimpangan hasil pembangunan misalnya dalam hal pendapatan perkapita atau pendapatan daerah, dan ketimpangan kegiatan atau proses pembangunan itu sendiri. Munculnya kawasan-kawasan kumuh di tengah beberapa kota besar, serta sebaliknya hadirnya kawasan-kawasan pemukiman mewah di tepian kota atau bahkan di pedesaan adalah suatu bukti nyata dari adanya suatu ketimpangan yang terjadi. Perbedaan gaya hidup masyarakat merupakan bukti lain dari ketimpangan. Distribusi pendapatan dibedakan menjadi dua ukuran pokok yaitu; distribusi ukuran, adalah besar atau kecilnya bagian pendapatan yang diterima masing-masing orang dan distribusi fungsional atau distribusi kepemilikan faktor-faktor produksi (Todaro, 2000).

Distribusi pendapatan dapat berwujud pemerataan maupun ketimpangan, yang menggambarkan tingkat pembagian pendapatan yang dihasilkan oleh berbagai kegiatan ekonomi. Distribusi dari suatu proses produksi terjadi setelah diperoleh pendapatan dari kegiatan usaha. Distribusi pendapatan mencerminkan ketimpangan atau meratanya hasil pembangunan suatu daerah atau Negara baik yang diterima masing-masing orang ataupun dari kepemilikan faktor-faktor produksi dikalangan penduduknya. Distibusi pendapatan merupakan faktor penting dalam menentukan keadaan kesejahteraan masyarakat pada umumnya (Sukirno, 2006).

Distribusi pendapatan yang didasarkan pada pemilik faktor produksi ini akan berkaitan dengan proses pertumbuhan pendapatan, adapun pertumbuhan pendapatan dalam masyarakat yang didasarkan pada kepemilikan faktor produksi dapat dikelompokkan menjadi dua macam:

1. Pendapatan karena hasil kerja yang berupa upah atau gaji dan besarnya tergantung tingkat produktivitas.
2. Pendapatan dari sumber lain seperti sewa, laba, bunga, hadiah, atau warisan. Sayangnya relevansi teori fungsional tidak mempengaruhi pentingnya peranan dan pengaruh kekuatan-kekuatan di luar pasar (faktor-faktor non-ekonomis) misalnya kekuatan dalam menentukan faktor-faktor harga.

\section{Pembangunan Ekonomi Daerah}

Salah satu cara dalam meningkatkan distribusi pendapatan adalah dengan adanya pelaksanaan pembangunan ekonomi. Suryono (2001), menyatakan bahwa pembangunan ekonomi merupakan suatu proses yang menyebabkan pendapatan perkapita penduduk atau suatu masyarakat meningkat dalam jangka panjang. Oleh karena itu perlu adanya pelaksanaan pembangunan ekonomi secara berkelanjutan dan dilakukan dengan baik, sebab dengan pelaksanaan pembangunan ekonomi, akan mendorong pertumbuhan ekonomi dan peningkatan distribusi pendapatan bagi masyarakat.

Pembangunan ekonomi merupakan suatu proses yang menyebabkan pendapatan perkapita penduduk atau suatu masyarakat meningkat dalam jangka panjang. Oleh karena itu perlu adanya pelaksanaan pembangunan ekonomi secara berkelanjutan dan dilakukan dengan baik, sebab dengan pelaksanaan pembangunan ekonomi, akan mendorong pertumbuhan ekonomi dan peningkatan distribusi pendapatan bagi masyarakat (Arsyad, 1999). Pembangunan ekonomi suatu Negara dinyatakan berhasil jika terjadi pertumbuhan ekonomi yang di iringi dengan berkurangnya ketimpangan pendapatan, sebaliknya jika semakin besar pendapatan perkapita semakin besar perbedaan antara kaum miskin dengan kaum kaya (Widodo, 1990). Pertumbuhan ekonomi yang terjadi memang bisa menurunkan jumlah orang miskin, yang mencerminkan peningkatan kesejahteraan rata-rata rakyat Indonesia. Namun, lapisan kelas atas tumbuh jauh lebih cepat ketimbang kelas pendapatan bawah yang tumbuh lamban, sehingga meng- 
hasilkan jurang antara kaya dan miskin yang semakin melebar. Semakin meningkatnya pertumbuhan ekonomi maka semakin tinggi pertumbuhan output perkapita dan meningkatnya daya beli masyarakat. Tingginya daya beli masyarakat akan meningkatkan kesejahteraan karena daya beli masyarakat merupakan salah satu indikator pendapatan (Mirza, 2012)

Pertumbuhan ekonomi disebabkan oleh barang modal, tenaga kerja dan perubahan produktivitas dari faktor produksi tersebut. Peningkatan investasi (barang modal) dapat berpengaruh terhadap pertumbuhan ekonomi, jika investasi bertambah maka pertumbuhan ekonomi pun meningkat dan jika investasi berkurang maka pertumbuhan ekonomi akan menurun (Bhinadi, 2003).

\section{PDRB (Produk Domestik Regional Bruto)}

PDRB adalah jumlah nilai tambah bruto (gross value added) yang timbul dari seluruh sektor perekonomian di suatu wilayah dalam jangka waktu tertentu. Pengertian nilai tambah bruto adalah nilai produksi (output) dikurangi dengan biaya antara (intermediate cost). Komponen-komponen nilai tambah bruto mencakup komponen-komponen faktor pendapatan (upah dan gaji, bunga, sewa tanah dan keuntungan), penyusutan dan pajak tidak langsung netto. Jadi dengan menghitung nilai tambah bruto dari masing-masing sektor dan kemudian menjumlahkannya akan menghasilkan Produk Domestik Regional Bruto (PDRB).

PDRB merupakan salah satu indikator penting untuk mengetahui kondisi ekonomi di suatu daerah dalam suatu periode tertentu, baik atas dasar harga berlaku maupun atas dasar harga konstan. PDRB pada dasarnya merupakan jumlah nilai tambah yang dihasilkan oleh seluruh unit usaha dalam suatu daerah tertentu, atau merupakan jumlah nilai barang dan jasa akhir yang dihasilkan oleh seluruh unit usaha dalam suatu daerah tertentu, atau merupakan jumlah nilai barang dan jasa akhir yang dihasilkan oleh seluruh unit ekonomi pada suatu daerah.

\section{Ketimpangan Distribusi Pendapatan}

Pendapatan merupakan suatu gambaran tingkat kemampuan seseorang dalam memenuhi kebutuhan materinya dalam satuan waktu tertentu, biasanya per bulan. Tingkat pendapatan ini sering dihubungkan dengan suatu standard kehidupan yang umum berlaku dalam masyarakat yang bersangkutan. Pendapatan dapat diperoleh seseorang dari mata pencaharian utama dengan atau tanpa mata pencaharian lain. Dengan demikian seseorang diharapkan mampu meningkatkan kesejahteraan keluarganya. Ketimpangan pendapatan lebih besar terjadi di negaranegara yang baru memulai pembagunannya, sedangkan bagi negara maju atau lebih tinggi tingkat pendapatannya cenderung lebih merata atau tingkat ketimpangannya rendah. Ketimpangan ekonomi adalah perbedaan pembangunan ekonomi antar suatu wilayah dengan wilayah lainnya secara vertical dan horizontal yang menyebabkan disparitas atau ketidakpemerataan pembangunan. Salah satu tujuan pembangunan ekonomi daerah adalah untuk mengurangi ketimpangan. Peningkatan pendapatan perkapita memang menunjukkan kemajuan perekonomian suatu daerah. Namun meningkatnya pendapatan perkapita tidak selamanya menunjukkan bahwa distribusi pendapatan lebih merata. seringkali dinegara-negara berkembang dalam perekonomiannya lebih menekankan penggunaan modal dari pada tenaga kerja sehingga keuntungan dari perekonomian tersebut harus di nikmati sebagian masyarakat saja. Apabila ternyata pendapatan nasional tida dinikmati secara merata oleh seluruh lapisan masyarakat, maka dapat dikatakan telah terjadi ketimpangan.

Dengan adanya pertumbuhan ekonomi baik secara langsung maupun tidak langsung akan berpengaruh terhadap masalah ketimpangan regional. Ketimpangan dalam pembagian pendapatan adalah ketimpangan dalam perkembangan ekonomi antara berbagai daerah pada suatu wilayah yang akan menyebabkan pula ketimpangan tingkat pendapatan perkapita antar daerah (Kuncoro, 2004). 
Ada 8 hal yang menyebabkan ketimpangan atau ketidakmerataan distribusi pendapatan di negara sedang berkembang :

1. Pertumbuhan penduduk yang tinggi yang mengakibakan menurunnya pendapatan perkapita.

2. Inflasi dimana pendapatan uang bertambah tetapi tidak diikuti secara proporsional dengan pertambahan produks barang-barang.

3. Ketidakmerataan pembangunan antar daerah.

4. Investasi yang sangat banyak dalam proyek-proyek yang padat modal (Capital Insentive), sehingga presentase pendapatan modal dari kerja tambahan besar dibandingkan dengan presentase pendapatan yang berasal dari kerja, sehingga pengangguran bertambah.

5. Rendahnya mobilitas social.

6. Pelaksanaan kebijakan industry substitusi impor yang mengakibatkan kenaikan harga-harga barang hasil industry untuk melindungi usaha-usaha golongan kapitalis.

7. Memburuknya nilai tukar (term of trade) bagi Negara sedang berkembang dalam perdagangan dengan Negaranegara maju, sebagai akibat ketidak elastisan permintaan Negara-negara maju terhadap barang-barang ekspor Negara sedang berkembang.

8. Hancurnya industri kerajinan rakyat seperti pertukangan, industri rumah tangga, dan lain-lain.

\section{Pertumbuhan Penduduk}

Pertumbuhan penduduk dinilai mampu mendorong pertumbuhan ekonomi. Bertambahnya penduduk akan memperluas pasar dan perluasan pasar akan mempertinggi tingkat spesialisasi dalam perekonomian (Irawan, 2002). Dalam hal ini teori klasik Adam Smith juga melihat bahwa alokasi sumber daya manusia yang efektif adalah pemula pertumbuhan ekonomi. Setelah ekonomi tumbuh, akumulasi modal (fisik) baru mulai dibutuhkan untuk menjaga agar ekonomi tumbuh. Dengan kata lain, alokasi sumber daya manusia yang efektif merupakan syarat perlu bagi pertumbuhan ekonomi.

Adanya pengaruh positif pertumbuhan penduduk terhadap pertumbuhan ekonomi di mana kondisi dan kemajuan penduduk sangat erat terkait dengan tumbuh dan berkembangnya usaha ekonomi. Penduduk di satu pihak dapat menjadi pelaku atau sumber daya bagi faktor produksi, pada sisi lain dapat menjadi sasaran atau konsumen bagi produk yang dihasilkan. Di pihak lain pengetahuan tentang struktur penduduk dan kondisi sosial ekonomi pada wilayah tertentu akan sangat bermanfaat dalam memperhitungkan berapa banyak penduduk yang dapat memanfaatkan peluang dan hasil pembangunan atau seberapa luas pangsa pasar bagi suatu produk usaha tertentu (Todaro, 2006).

Pertumbuhan penduduk setiap tahun akan berdampak pada usia kerja yang mempengaruhi pertumbuhan maupun jumlah angkatan kerja. Pembangunan ketenaga kerjaan ditujukan untuk memperluas lapangan kerja produktif, baik jumlah maupun mutunya. Jumlah penduduk yang berumur produktif baik yang sudah bekerja maupun yang belum bekerja, akan meningkatkan angka ketimpangan distribusi pendapatan. Hal ini dikarenakan proporsi jumlah penduduk yang bekerja masih belum merata di sejumlah daerah, mereka masih banyak yang bekerja di pedesaan dibandingkan di perkotaan, sehingga terjadi perbedaan penghasilan antar mereka yang bekerja di kota dan mereka yang bekerja di desa. Mereka yang bekerja di perkotaan memiliki tingkat penghasilan yang tinggi jika dibandingkan dengan mereka yang bekerja di pedesaan (Musfidar, 2012).

\section{Indeks Gini}

Ukuran Indeks Gini yang melihat adanya hubungan antara jumlah pendapatan yang diterima oleh seluruh keluarga atau individu dengan total pendapatan. Ukuran Indeks Gini sebagai ukuran pemerataan pendapatan mempunyai selang nilai antara 0 
sampai dengan 1. Bila Indeks Gini mendekati nol menunjukkan adanya ketimpangan yang rendah dan bila Indeks Gini mendekati satu menunjukkan ketimpangan yang tinggi (Todaro, 2006).

Rumus yang dipakai untuk menghitung nilai Indeks Gini adalah :

$$
\mathrm{G}=1-\sum_{i=1}^{k} \frac{P_{i}\left(Q_{i}+Q_{i-1}\right)}{10000}
$$

Keterangan :

$\mathrm{G} \quad=$ Indeks Gini

$\mathrm{Pi} \quad=$ Persentase rumah tangga pada kelas pendapatan ke-i

Qi = Persentase kumulatif pendapatan sampai dengan kelas-i

Qi-1 = Persentase kumulatif pendapatan sampai dengan kelas ke-i

$\mathrm{k}=$ = Banyaknya kelas pendapatan

Kriteria ketimpangan pendapatan berdasarkan Indeks Gini adalah sebagai berikut :

-Ketimpangan tinggi jika Indeks Gini > 0,5

-Ketimpangan sedang jika Indeks Gini 0,4 0,5

-Ketimpangan rendah jika Indeks Gini $<0,4$

Nilai Indeks Gini antara 0 dan 1, dimana nilai 0 menunjukkan tingkat pemerataan yang sempurna, dan semakin besar nilai Indeks Gini maka semakin tidak sempurna tingkat pemerataan pendapatan.

\section{Indeks Williamson}

Indeks Williamson yang diperkenalkan oleh Williamson, merupakan metode untuk mengukur ketidakmerataan regional. Metode ini diperoleh dari perhitungan perkapita dan jumlah penduduk di suatu negara. Secara sistematis perhitungan Indeks Williamson adalah sebagai berikut :

$$
\mathrm{IW}=\frac{\sqrt{\sum(\mathrm{Yi}-\mathrm{Y})^{2} \mathrm{fi} / \mathrm{n}}}{\mathrm{Y}}
$$

Dimana :

IW = Indeks Williamson

$\mathrm{Yi} \quad=$ PDRB perkapita di Kabupaten/kota $\mathrm{i}$

$\overline{\mathrm{Y}} \quad=$ PDRB rata-rata per kapita di Provinsi

fi = Jumlah penduduk di Kabupaten/kota i

$\mathrm{n}=$ Jumlah penduduk di Provinsi.
Besarnya Indeks Williamson ini bernilai positif dan berkisar antara angka nol sampai dengan satu. Semakin besar nilai indeks ini (mendekati angka satu) berarti semakin besar tingkat ketimpangan pendapatan antar daerah dalam wilayah tersebut. Sebaliknya semakin kecil nilai index ini (mendekati angka nol) berarti semakin merata tingkat pemerataan pendapatan antar daerah dalam wilayah tersebut.

Kriteria untuk mengetahui tingkat ketimpangan pendapatan antar daerah, apakah ada ketimpangan tinggi, sedang atau rendah. Untuk itu ditentukan kriteria sebagai berikut :

-Ketimpangan Tinggi jika IW > 0,5

-Ketimpangan Sedang jika IW $=0,35-0,5$

-Ketimpangan Rendah jika IW $<0,35$.

Namun demikian Index Williamson ini mempunyai kelemahan yakni penghitungan ini baru menggambarkan tingkat pendapatan secara global sejauh mana dan berapa besar bagian yang diterima oleh kelompok yang berpendapatan rendah atau miskin bertambah tidak tampak dengan jelas (Sjafrizal, 2008).

\section{Rumusan Masalah}

Berdasarkan latar belakang, maka perumusan masalah adalah bagaimana distribusi pendapatan antar daerah pada tingkat Kabupaten dan Kota di Provinsi Sulawesi Utara?

\section{Tujuan Penelitian}

Berdasarkan perumusan masalah, maka yang menjadi tujuan penelitian ini untuk mengetahui distribusi pendapatan antar daerah pada tingkat Kabupaten dan Kota di Provinsi Sulawesi Utara.

\section{Manfaat Penelitian}

untuk:

Kegunaan penelitian ini bermanfaat

1. Bagi pemerintah Sulawesi Utara sebagai sumber informasi tentang pendapatan distribusi antar daerah di Provinsi Sulawesi Utara.

2. Bagi peneliti sebagai suatu analisis untuk mengetahui distribusi pendapatan daerah di Provinsi Sulawesi Utara. 
3. Bagi mahasiswa atau yang memerlukan, dapat di jadikan referensi kajian dalam bidang penelitian serupa.

\section{METODOLOGI PENELITIAN}

\section{Lokasi Dan Waktu Penelitian}

Penelitian dilakukan dari bulan Oktober 2017 sampai bulan Februari 2018 di Provinsi Sulawesi Utara.

\section{Jenis Data}

Penelitian ini menggunakan data Sekunder. Data tersebut dikumpulkan dan diperoleh dari Badan Pusat Statistik Provinsi Sulawesi Utara dan dinas-dinas pemerintah lainnya yang terkait.

\section{Konsepsi Pengukuran Variabel}

Adapun variabel-variabel yang diukur dalam penelitian ini mencakup :

1. Jumlah Penduduk adalah jumlah penduduk Provinsi Sulawesi Utara dan Kabupaten/kota (jiwa/tahun) kurun waktu tahun 2012-2016

2. Produk Domestik Regional Bruto (PDRB), adalah seluruh nilai tambah produk yang dihasilkan yang ditimbulkan dari beberapa sektor perekonomian di Provinsi Sulawesi Utara menurut lapangan usaha atas dasar harga konstan tahun 2012-2016

3. Rata-rata pengeluaran atau pendapatan rumah tangga yang dihasilkan di Provinsi Sulawesi utara.

\section{Analisis Data}

Guna untuk mengetahui distribusi pendapatan antar daerah di Provinsi Sulawesi Utara dapat di analisis dengan menggunakan indeks ketimpangan Williamson, yaitu merupakan salah satu alat ukur untuk mengukur tingkat ketimpangan daerah atau disparitas pendapatan di suatu wilayah. Adapun Indeks Williamson di formulasikan sebagai berikut :

$$
\mathrm{IW}=\frac{\sqrt{\sum(\mathrm{Yi}-\mathrm{Y})^{2} \mathrm{fi} / \mathrm{n}}}{\mathrm{Y}}
$$

Keterangan:

IW = Indeks Williamson

Yi $=$ PDRB per kapita di kabupaten ke $\mathrm{i}$

$\overline{\mathrm{Y}} \quad=$ PDRB rata-rata per kapita di Provinsi

fi = jumlah penduduk kabupaten ke $\mathrm{i}$

$\mathrm{n} \quad=$ jumlah penduduk Provinsi

Kriteria untuk mengetahui tingkat ketimpangan pendapatan antar daerah, apakah ada ketimpangan tinggi, sedang atau rendah. Untuk itu ditentukan kriteria sebagai berikut :

-Ketimpangan Tinggi jika IW > 0,5

-Ketimpangan Sedang jika IW $=0,35-0,5$

-Ketimpangan Rendah jika IW $<0,35$.

\section{HASIL DAN PEMBAHASAN}

\section{Gambaran Umum Provinsi Sulawesi Utara}

Berdasarkan posisi geografisnya, Provinsi Sulawesi Utara terletak di jazirah utara Pulau Sulawesi dan merupakan salah satu dari tiga Provinsi di Indonesia yang terletak di sebelah utara garis khatulistiwa. Dilihat dari letak geografis Provinsi Sulawesi Utara terletak pada $0^{\circ} \mathrm{LU}-3^{\circ} \mathrm{LU}$ dan $123^{\circ} \mathrm{BT}-126^{\circ} \mathrm{BT}$.

Luas Wilayah Sulawesi Utara tercatat $13,850 \mathrm{~km}^{2}$ yang terbagi atas 11 Kabupaten dan 4 Kota. Jumlah penduduk di wilayah Provinsi Sulawesi Utara pada tahun 2016 adalah 2436 921 jiwa di wilayah Kabupaten dan Kota di Provinsi Sulawesi Utara, dimana jumlah penduduk terbanyak berada di wilayah Kota Manado dengan jumlah 427906 jiwa, yang kemudian diikuti oleh jumlah penduduk di wilayah Kabupaten Minahasa dengan jumlah 332190 jiwa. Sedangkan jumlah penduduk tersedikit berada di wilayah Bolaang Mongondow Timur dengan jumlah 68692 jiwa, yang disusul oleh jumlah penduduk di wilayah Kabupaten Bolaang Mongondow Selatan dengan jumlah 63207 jiwa.

\section{Perkembangan Tingkat Kemiskinan di Sulawesi Utara}

Masalah kemiskinan merupakan salah satu persoalan mendasar yang menjadi pusat perhatian di seluruh nagara khususnya di Provinsi Sulawesi Utara. gambaran juga tentang kebutuhan sosial, termasuk keterkucilan sosial biasanya di bedakan dari 
kemiskinan, karena hal ini mencakup masalah-masalah politik dan moral dan tidak dibatasi pada bidang ekonomi. Gambaran tentang kurangnya penghasilan dan kekayaan yang memadai dengan mencari objek penghasilan di luar profesi secara halal. Kompleksnya masalah kemiskinan membuatnya terus menjadi masalah fenomenal di belahan dunia khususnya di Provinsi Sulawesi Utara. Berdasarkan Tabel 1 tingkat kemiskinan Kabupaten / Kota di Provinsi Sulawesi Utara terjadi fluktuatif dari tahun ke tahun.

\begin{tabular}{|c|c|c|c|c|c|}
\hline Kabupaten/Kota & 2012 & 2013 & 2014 & 2015 & 2016 \\
\hline Kab Bolaang Mongondow & 7.68 & 8.91 & 8.59 & 8.63 & 8.34 \\
\hline Kab Minahasa & 7.16 & 8.81 & 8.53 & 8.80 & 8.36 \\
\hline Kab Kepulauan Sangihe & 10.66 & 12.19 & 11.84 & 12.27 & 12.28 \\
\hline Kab Kepulauan Talaud & 9.06 & 10.27 & 9.92 & 10.09 & 10.29 \\
\hline Kab Minahasa Selatan & 8.61 & 10.08 & 9.85 & 10.22 & 9.92 \\
\hline Kab Minahasa Utara & 6.69 & 8.02 & 7.75 & 8.12 & 7.90 \\
\hline Kab Bolaang Mongondow Utara & 8.01 & 9.61 & 9.27 & 9.72 & 9.38 \\
\hline Kab Kepulauan Sitaro & 9.48 & 11.36 & 11.03 & 10.93 & 10.58 \\
\hline Kab Minahasa Tenggara & 14.24 & 16.10 & 15.76 & 15.88 & 14.71 \\
\hline Kab Bolaang Mongondow Selatan & 15.07 & 15.28 & 15.00 & 15.17 & 14.85 \\
\hline Kab Bolaang Mongondow Timur & 6.20 & 6.92 & 6.61 & 6.90 & 6.77 \\
\hline Kota Manado & 4.91 & 4.88 & 4.81 & 5.63 & 5.24 \\
\hline Kota Bitung & 7.45 & 6.45 & 6.34 & 6.87 & 6.57 \\
\hline Kota Tomohon & 5.82 & 6.57 & 6.32 & 6.78 & 6.56 \\
\hline Kotamobagu & 5.85 & 5.98 & 5.75 & 5.85 & 6.01 \\
\hline Sulawesi Utara & 7.63 & 8.50 & 8.26 & 8.65 & 8.34 \\
\hline
\end{tabular}

Dengan melihat Tabel 1 pada tahun 2012 ke tahun 2013 mengalami kenaikan dari 7,63 persen menjadi 8,50 persen kemudian tingkat kemiskinan Sulawesi Utara menunjukkan trend positif dengan mengalami penurunan 8,26 persen pada tahun 2014, tetapi naik kembali 8,65 persen di tahun 2015 dan tingkat kemiskinan Sulawesi Utara kembali mengalami tanda positif dengan mengalami penurunan menjadi 8,34 persen di tahun 2016.

\section{Hasil Analisis Data}

\section{Indeks Gini Ratio Kabupaten/Kota di Sulawesi Utara}

Hasil pengukuran Indeks Gini dengan melihat data BPS dihitung pada tahun 2012 2016, berdasarkan Tabel 2.
Tabel 2. Gini Ratio Provinsi Sulawesi Utara Menurut Kabupaten / Kota Tahun 2012-2016

\begin{tabular}{lccccc}
\hline \multicolumn{1}{c}{ Kabupaten/Kota } & $\mathbf{2 0 1 2}$ & $\mathbf{2 0 1 3}$ & $\mathbf{2 0 1 4}$ & $\mathbf{2 0 1 5}$ & $\mathbf{2 0 1 6}$ \\
\hline Kab Bolaang Mongondow & 0.36 & 0.38 & 0.34 & 0.30 & 0.31 \\
Kab Minahasa & 0.41 & 0.39 & 0.38 & 0.36 & 0.36 \\
Kab Kepulauan Sangihe & 0.34 & 0.35 & 0.38 & 0.34 & 0.36 \\
Kab Kepulauan Talaud & 0.37 & 0.38 & 0.39 & 0.26 & 0.37 \\
Kab Minahasa Selatan & 0.37 & 0.38 & 0.36 & 0.38 & 0.35 \\
Kab Minahasa Utara & 0.45 & 0.44 & 0.40 & 0.35 & 0.43 \\
Kab Bolaang Mongondow Utara & 0.34 & 0.37 & 0.38 & 0.33 & 0.38 \\
Kab Kepulauan Sitaro & 0.33 & 0.28 & 0.30 & 0.32 & 0.35 \\
Kab Minahasa Tenggara & 0.38 & 0.34 & 0.33 & 0.30 & 0.30 \\
Kab Bolaang Mongondow Selatan & 0.37 & 0.40 & 0.35 & 0.35 & 0.32 \\
Kab Bolaang Mongondow Timur & 0.33 & 0.33 & 0.33 & 0.30 & 0.30 \\
Kota Manado & 0.41 & 0.40 & 0.43 & 0.39 & 0.35 \\
Kota Bitung & 0.46 & 0.42 & 0.43 & 0.39 & 0.35 \\
Kota Tomohon & 0.41 & 0.41 & 0.38 & 0.32 & 0.35 \\
Kota Kotamobagu & 0.41 & 0.39 & 0.39 & 0.35 & 0.41 \\
\hline \multicolumn{1}{c}{ Sulawesi Utara } & 0.43 & 0.42 & 0.42 & 0.37 & 0.39 \\
\hline Sumber data BPS, diolah & & & & &
\end{tabular}

Berdasarkan Tabel 2 ketimpangan distribusi pendapatan di Kabupaten/kota pada tahun 2012 sampai tahun 2016 menunjukkan terjadinya fluktuasi. Nilai Indeks Gini pada tahun 2012 0,43 turun menjadi lebih merata di tahun 2016 dengan nilai Indeks Gini 0,39, ini mengidentikasikan bahwa distriusi pendapatan di Sulawesi Utara relatif merata. Kabupaten/Kota nilai Indeks Gini yang cenderug menurun terjadi di Kabupaten Minahasa dari nilai Indeks Gini 0,41 turun menjadi 0,36 di tahun 2016. Nilai Indeks Gini Kota Bitung juga di tahun 2012 dari 0,46 naik di tahun 2014 tetapi secara umum mengalami penurunan nilai Indeks Gini di tahun 2016 menjadi 0,35. Secara umum Kabupaten/Kota yang nilai Indeks Gini tertinggi atau mengalami ketidakmerataan pendapatan terjadi di Kabupaten Minahasa Utara dari tahun 2012 sampai tahun 2016 dengan kisaran nilai Indeks Gini 0,45 sampai 0,43 walaupun masih termasuk dalam ketimpangan sedang. Sementara itu nilai Indeks Gini terendah terjadi di Kabupaten Minahasa Tenggara dan Kabupaten Bolaang Mongondow dimana nilai Indeks Gininya masing-masing 0,30 dan 0,31 di tahun 2016. Tetapi juga ada daerah-daerah yang nilai Indeks Gininya relatif merata seperti Kabupaten sangihe, Kabupaten Kepulauan Sitaro, Kabupaten Kepulauan Talaud, Kabupaten Bolaang Mongondow Timur dan Kabupaten Bolaang Mongondow Utara. Tetapi 
walaupun secara umum pendapatan di Kabupaten/Kota ini merata tetapi pemerataan tersebut bukan berarti menunjukkan tingkat kemakmuran, karena ternyata Kabupaten Minahasa Tenggara dengan nilai Indeks Gininya merata tetapi tingkat kemiskinannya sangat tinggi, artinya kemungkinan besar di Kabupaten Minahasa Tenggara, tingkat pendapatannya merata tetapi dalam tingkat pendapatan yang rendah.

Dan mengidentikasikan bahwa di daerahdaerah tersebut ada sekelompok masyarakat yang memiliki pendapatan yang tinggi dan ada sekelompok masyarakat yang memiliki pendapatan yang rendah, hal ini dapat juga di sebabkan karena sangat bervariasinya peluang atau kesempatan untuk meningkatkan pendapatan, yang menyebabkan perbedaan pendapatan yang terjadi di masyarakat khususnya di Provinsi Sulawesi Utara.

\section{Distribusi dan Ketimpangan Pendapatan Antar Daerah di Provinsi Sulawesi Utara (Indeks Williamson)}

Tingkat ketimpangan wilayah antar Kabupaten/Kota memberikan gambaran tentang perkembangan pembangunan di Kabupaten/ Kota di Provinsi Sulawesi Utara. Untuk memberikan gambaran tentang kondisi, perkembangan daerah diwilayah Provinsi Sulawesi Utara yang dilihat dari PDRB per kapita antar Kabupaten/Kota dan bisa dilihat pada Tabel 3 Indeks Williamson Provinsi Sulawesi Utara.

Tabel 3. Indeks Williamson Provinsi Sulawesi Utara Tahun 2012 - 2016

\begin{tabular}{cc} 
Utara Tahun $\mathbf{2 0 1 2} \mathbf{- 2 0 1 6}$ & \\
\hline Tahun & Indeks Williamson \\
\hline 2012 & 0,47 \\
2013 & 0,47 \\
2014 & 0,48 \\
2015 & 0,48 \\
2016 & 0,54 \\
\hline
\end{tabular}

Sumber: Data Olahan

Tabel 3 menunjukkan ketimpangan antar Kabupaten/Kota di Provinsi Sulawesi Utara dari tahun 2012 sampai Tahun 2016 ada kecenderungan naik, pada tahun 2012 nilai Indeks Williamson sebesar 0,47 naik menjadi 0,54 pada tahun 2016. Berdasarkan hal tersebut, dapat diartikan bahwa antar Kabupaten/Kota di Provinsi
Sulawesi Utara terjadi ketimpangan pendapatan yang relatif tinggi. Hal ini tidak terlepas dari perbedaan kemampuan tiap daerah, juga faktor pemilikan sumber daya alam dan persebaran penduduk yang berimplikasi terhadap nilai tambah bruto (PDRB) dalam perekonomian antar daerah. Dari tahun 2012 Sampai tahun 2016 Indeks Williamson cenderung meningkat, pada tahun 2012 tingkat kesenjangan Kabupaten/Kota di Provinsi Sulawesi Utara adalah 0,47 dan pada tahun 2013 tingkat kesenjangan naik dari tahun sebelumnya menjadi 0,47 dan pada tahun 2014 dan 2015 terjadi tingkat kesenjangan pendapatan dengan nilai Indeks Williamson masing-masing 0,48 .

Pada tahun 2016 menjadi tahun yang tingkat kesenjanganya meningkat di-bandingkan dengan tahun-tahun sebelumnya dengan Indeks Williamson 0,54 dan jika di sesuaikan dengan kriteria Indeks Williamson, tahun 2016 menjadi tahun yang tingkat ketimpangannya tinggi dan ini meng-identikasikan bahwa pembangunan wilayah yang terjadi di Kabupaten/Kota di Provinsi Sulawesi Utara pada tahun 2016 mengalami peningkatan ketimpangan pendapatan antar wilayah dari kategori sedang menjadi tinggi atau pembangunan wilayah tidak merata. Perbedaanperbedaan tersebut yang meng-akibatkan terjadinya kesenjangan khususnya di Provinsi Sulawesi Utara yang menyebabkan perbedaan pendapatan dan tidak meratanya pembangunan yang hanya terfokus pada daerah-daerah tertentu saja sehingga meng-akibatkan kesenjangan dan ini terlihat jelas dengan perbedaan gaya hidup masyarakat yang juga merupakan bukti lain dari ketimpangan khususnya yang terjadi di Provinsi Sulawesi Utara.

\section{KESIMPULAN DAN SARAN}

\section{Kesimpulan}

Distribusi pendapatan antar Kabupaten/Kota di Sulawesi Utara meningkat dari ketidakmerataan sedang pada tahun 2012 (IW $=0,47)$ menjadi ketidakmerataan tinggi pada tahun 2016 (IW = 0,54). Distribusi pendapatan di Sulawesi Utara berdasarkan Indeks Gini Sulawesi Utara relatif merata ditunjukan dengan nilai Indeks Gini pada tahun 2012 0,43 turun menjadi lebih merata di tahun 2016 dengan nilai Indeks Gini 0,39. 


\section{Saran}

Adanya ketimpangan pendapatan perkapita antar daerah menyebabkan pentingnya bantuan pembangunan dari pemerintah pusat kepada daerah-daerah yang tertinggal dan hendaknya disesuaikan dengan situasi dan kondisi di daerah masing-masing sehingga diharapkan daerah yang tertinggal mampu mengejar daerah yang sudah maju. Bagi Kabupaten/Kota yang masuk dalam daerah sudah maju memberikan bantuan bagi daerah tertinggal berupa pembiayaan program pemberdayaan masyarakat yang dapat meningkatkan kualitas sumber daya manusia.

\section{DAFTAR PUSTAKA}

Badan Pusat Statistika (BPS) Provinsi Sulawesi Utara. 2012 - 2016. Data Jumlah Penduduk Provinsi Sulawesi Utara.
Badan Pusat Statistik (BPS) Provinsi Sulawesi Utara. 2017.Data Tingkat Kemiskinan.

Kuncoro, 2004. Teori Pembangunan Ekonomi. Balai Pustaka. Jakarta.

Rustiadi, 2011. Perencanaan dan Pengembangan Wilayah. Crestpen Press Dan Yayasan Pustaka Obor Indonesia. Jakarta.

Sjafrizal. 2008. Ekonomi Regional Teori dan Aplikasi. Baduose Media.Padang Sumatera Barat.

Tambunan. 2001. Perekonomian Indonesia: Teori dan Temuan Empiris, Ghali Indonesia, Jakarta.

Todaro, Michael P. 2000. Ekonomi Pembangunan. Erlangga. Jakarta.

Todaro M.P. 2006. Pembangunan Ekonomi di Dunia Ketiga, PT Erlangga, Jakarta. 